\title{
The Cost of Education: A Study on the Cost of Education in the Faculty of Educational Sciences at Ankara University ${ }^{*}$
}

\author{
Ali Ilker KURT ${ }^{* *}$ \\ Hasan Huseyin AKSOY A** $^{* *}$
}

\begin{abstract}
After the 1970's, public sphere decreased depending on the constrains of public service have been reformed by the pressure of neo-liberal policies. Decreasing have emerged both in public expenditure and the opportunity to be involved in public education, especially in higher education. In this context, in this research it has been figured out that there is a decrease in the expenditure of higher education. By this study, how the impact of decreasing in public expenditure viewed at the faculty level, and at which level public expenditures were realized, the size of the cost that students have to endure in order to maintain their education, the effects of these costs on students' maintaining their education and finally students' opinions about opportunity cost has been displayed.
\end{abstract}

Key words: higher education cost, opportunity cost, financing higher education, educational public expenditures, personal educational expenditures

\footnotetext{
* Data of the research have been gathered from the Master Thesis prepared by Ali Ilker Kurt and Advised by Assoc. Prof. Dr. Hasan Huseyin Aksoy. The reference of the resource is: Ali Ilker Kurt. (2007). The Cost Education : A Study on the Cost of Education in the Faculty of Educational Sciences at Ankara University. Unpublished Master Thesis. A.U. Institute of Educational Sciences. Ankara.

${ }^{* *}$ Doctoral Student, Ankara University, Institute of Education Sciences . Dept. of Economics and Planning of Education

${ }^{* * *}$ Assoc. Prof. Dr., Ankara University, Faculty of Educational Sciences, Dept. of Educational Administration and Policy, aksoy@education.ankara.edu.tr
} 


\section{SUMMARY}

Purpose: This study aims at identify the cost of education in the Faculty of Educational Sciences at Ankara University. Within this context, the public cost of education has been calculated by using the government's spending on education, personal expenditure by parents and students, and opportunity cost. To this end, the progress of public spending on education in the Faculty of Educational Sciences at Ankara University between 1990 and 2005 was portrayed and the students' personal expenses were identified through a data collection instrument administered to the students,. In addition, the opportunity cost was determined based on students' opinion. All these led to the calculation of the total cost of education. The cost per student was calculated according to the amount of the public cost, while the average cost per graduate was calculated using the number of graduates. Further, the public spending between 1990 and 2005 was calculated through using the semi-logarithmic structure of the temporal progress of the number of students and the number of the lecturers, and analyzed through graphs drawn according to the calculations.

Method: The study was designed in a descriptive survey model. The data collection was made by a questionnaire designed by the researchers. The questionnaire was administered to the 636 students attending to the Faculty of Educational Sciences at Ankara University through the educational year 2006-2007. As a result of the study, it was observed that the current expenses tended to decline, investment and transfer expenditures were irregular progressed, and raising the numbers of the students outnumbered the lecturers'.

Results and Discussion: As for personal expenses of the students, it was seen that the students had to spend almost as much as the public spending. Further, it was observed that the average income of students, including the monthly money they received from their parents and the scholarships, fell much behind their monthly expenditure, which made them face a lot of difficulties. It can be stated that the level of spending is high, while they have not enough income to meet this has a negative influence on students. Despite the financial problems students face, they struggle to continue their education. In addition, it was revealed that there was no significant difference between the faculty programmes attended and the socio-cultural and economic structures of the families.

Conclusion. In conclusion, in parallel with the reduction in the higher education expenditure at all across the country, the cost per student as well as the spending per graduate has gone down. On the other hand, though the number of students is on the increase, contrary to lecturers' numbers are still not high enough. Finally, it is seen that families are negatively affected by the fact that personal expenses of students are high, while the public spending on education is decreasing. 


\title{
Eğitimde Maliyet: Ankara Üniversitesi Eğitim Bilimleri Fakültesi'nde Sürdürülen Eğitimin Maliyeti Üzerine Bir Araştırma $^{*}$
}

\begin{abstract}
Ali İlker Kurt**
Hasan Hüseyin AKSOY***

ÖZ. 1970'li yıllardan sonra dünyada kapitalist ülkelerdeki mali krizle birlikte, kamusal olarak belirlenen alanların giderek daraldığ 1 , bununla birlikte kamusal hizmetlerin sınırlarının neoliberal politikalar yardımıyla yeniden çizildiği görülmektedir. Bu gelişmeler, eğitimde, özellikle yükseköğretimde giderek kamusal harcamaların ve kamusal hizmetten yararlanma olanaklarının azalmasına neden olmaktadır. $\mathrm{Bu}$ bağlamda Türkiye genelinde yapılan araştırmalarda yükseköğretimde kamusal harcamalarda gerileme olduğu belirlenmiştir. Bu çalışma ile kamusal harcamalardaki daralmanın etkilerinin bir fakülte düzeyinde nasıl yaşandığı, kamusal harcamaların hangi düzeyde gerçekleştiği, öğrencilerin eğitimlerini sürdürmek için katlandıkları maliyetin boyutları ve bu maliyetlerin öğrencilerin eğitimlerini sürdürmelerine olan etkileri, öğrencilerin firsat maliyeti hakkındaki düşünceleri ortaya konmuştur.
\end{abstract}

Anahtar Sözcükler: Yükseköğrenim maliyeti, firsat maliyeti, yükseköğretimin finansmanı, kamusal eğitim harcamaları, kişisel eğitim harcamaları

\footnotetext{
Araştırma verileri Doç. Dr. Hasan Hüseyin Aksoy danışmanlığında Ali İlker Kurt tarafından A.Ü. Eğitim Bilimleri Enstitüsü'nde gerçekleştirilen yüksek lisans tezi araştırmasından alınmıştır.

** A.Ü. Eğitim Bilimleri Enstitüsü, Eğitim Ekonomisi ve Planlaması, Doktora Öğrencisi

*** Doç. Dr. A.Ü. Eğitim Bilimleri Fakültesi Öğretim Üyesi, Aksoy@education.ankara.edu.tr
} 


\section{GíRISS}

Tarihsel olarak 1970'lerin sonlarına kadar geçen sürede eğitimin temel bir hak olarak devlet tarafından kamusal bir hizmet olarak sunulduğu ve eğitimden toplumun geniş kesimlerince doğrudan, piyasa ve fiyat mekanizmasına bağlı olmadan arz miktarının getirdiği sınırlılıklar çerçevesinde yararlanılabildiği söylenebilir.

Öncelikle yükseköğretimde bireysel getiri düzeyinin, toplumsal getiri düzeyinden yüksek olduğu şeklindeki vurguyla, yükseköğretim düzeyinde yükseköğretimden faydalananların bu hizmetin bedeline katlanmaları gerektiği şeklindeki görüşler yoluyla eğitimin kamusal hizmet olarak piyasadan bağımsız sunulması sorgulanmaya başlanmıştır (Psacharapoulos, 1991, çev. Aksoy, 1995). İlerleyen dönemlerde üniversitelerin gelirleri arasında uluslararası kaynaklı "projelerin" daha çok yer tutmaya başlaması ve genel olarak bütçeden ayrılan kaynaklarda kesintiye gidilmesi, "işletmeci üniversite", "işletme gibi yönetilen üniversite" kavramlarının hayata geçirilmeye çalışılması ise uzun dönemde kamusal nitelikte olan eğitimin ve "eğitim hakkı"na erişimin var olan düzeyde dahi sürdürülemeyeceğini göstermektedir (Aksoy, 2005,5).

Eğitimin özel mal olduğu yönündeki vurguların arttığı bir dönemde 2325 Haziran 2003 y1lında Unesco tarafindan 120 ülkeden katılımla toplanan Yükseköğretim Paydaşları Toplantısı'nda (Meeting of Higher Education Partners), yükseköğretim insan haklarından biri olarak görülmüş ve yükseköğretimin "kamusal mal" olduğunun vurgulanması, bu vurguyu da özellikle yükseköğretim alanında gerçekleşen gerileme ve mezunların istihdam sorunlarındaki artışla birlikte kamusal sorumluluğun hatırlatılması sorunun düzeyi açısından önemli bir aşamayı göstermektedir (Unesco, 2003, Akt. Aksoy, 2005,7).

Yükseköğretimde 1980'lerden itibaren gelişmiş ve gelişmekte olan ülkelerde gündeme gelen üniversite reformları ve yükseköğretimle ilgili politika değişikliklerinin odak noktasını finansmanla ilgili yeni düzenlemeler oluşturmaktadır (Ünal, 1986,333).

Küreselleşmenin yükseköğretime etkilerini inceleyen Slaughter ise bu değişikliklerle ilgili olarak ortaya çıkan değişmeleri dört gruba ayırmıştır (Akt. Tural, 2004,98):

1-Yükseköğretim finansmanında daralma,

2-Tekno-bilime verilen öncelik,

3-Çok uluslu şirketlerle gelişen ilişkiler,

4-Fikri Mülkiyete (intellectual property) odaklanma. 
$\mathrm{Bu}$ değişikliklerin bir kısmı, Türkiye yükseköğretim harcamalarının değişiminin çok genel olarak izlenmesi yoluyla dahi görülebilmektedir. Türkiye'de yükseköğretim harcamalarının konsolide bütçeye oranı 1970'te $\%$ 2.2, 1980'de \% 4.4, 1990'da \% 5.8, 1997'de \% 3,18, 1999'da \% 2,49, 2000 yılında ise \% 2.26 olmuştur. Daha yakın bir tarihte katma bütçeden yükseköğretime ayrılan ödeneğin konsolide bütçeye oranı 2003'te \% 2.27'ye düşmüştür. 2005 yılında bu oranın \% 3,34 olduğu görülmektedir (MEB, Milli Eğitim İstatistikleri). Tural $(2004,240)$, öğrenci sayılarındaki artışa karşın, bütçedeki daralmanın üniversiteleri güç duruma düşürdügünü, yeni kaynak bulma yönünde arayışlara ittiğini ifade etmektedir.

Üniversitelerdeki finansal yapının 1960'l1 y1llardan 2000'li yıllara gelinceye kadar belirgin ş̧ekilde değiştiği, 1960'lı y1llarda üniversite eğitiminin devlet tarafindan yapılmasının uygun olacağ 1 vurgulanırken, 1980'li yıllardan sonra devletin hizmet alanlarında değişimler yaşandığ 1 ve devletin görev alanlarının yeniden tanımlandığı, özellikle eğitim ve sağlık gibi hizmetlerin son 30 yıllık dönemde özel kişi ya da kuruluşlarca da yapıldığı ve çeşitli yardımlarla bu faaliyetlerin özendirildiği görülmektedir (Karakütük, 2001,70-74).

Ergen'in $(1999,106)$, araștırmasında kamu eğitim harcamalarının konsolide bütçe harcamaları içindeki payının 1992 yılından beri sürekli olarak düştüğü bulgulanmıştır. 1983-1997 döneminde personel harcamalarında çok büyük gerilemeler gözlenmezken; kamu kaynaklarından eğitime ayrılan personel dışı cari, yatırım ve transfer harcamalarının ilgili konsolide bütçe harcama türleri içindeki paylarında düzenli düşme olduğu görülmektedir. Çalışmada GSMH'nin yılda ortalama \% 6 büyüdüğü ve konsolide bütçe harcamalarının GSMH içindeki payı sürekli artarken, eğitimin konsolide bütçe içindeki payının azalmasının eğitim maliyetinin giderek ailelere yüklenmesi yönünde bir eğilimi gösterdiği değerlendirmesi yapılmaktadır.

Nazenin'in $(2002,164)$ yükseköğretim harcamalarının değișimi üzerine yaptığ 1 çalışmada, devlet üniversitelerine ayrılan kaynaklarda yükseköğretimde artan talebe rağmen öğrenci başına ortalama cari harcamalarda (birkaç istisna dişında) düşmeler görüldüğünü, yatırım harcamalarının düştügünü ifade etmektedir. Araştırmada belirtilen sonucun Türkiye'de uygulanan neoliberal politikalar bağlamında ele alınması gerektiği ve 1985-2001 yılları arasında Türkiye'de öğrencilerden alınan katkı paylarının artış eğilimi içinde olduğu, devletin üniversitelere yaptığ 1 kamu harcamalarını kısarken, öğrencilerden aldığ 1 cari hizmet ödeneğinin giderek arttığı, bu durumun eğitimi bir meta olarak tanımlayan ve eğitim hizmetinin maliyetini hizmetten yararlanan öğrencilere ya da ailelerine yükleyen eğitim politikalarının sonucu olduğu ifade edilmektedir (Nazenin, 2002). 
Yükseköğretim öğrencilerine yönelik profil sunan Özsoy’un $(2002,294)$ bir “vakıf", bir "büyükkent", bir de "küçükkent" üniversitesi öğrencilerinden seçilen bir örnekleme dayalı araştırma sonuçlarına göre, altılı gruplamaya ayrilan ailelerin gelir durumları, ikili kategoriler olarak yeniden gruplandırıldığında dikkat çekici bulgulara ulaşılmıştır. 400 milyondan daha az görece en düşük gelire sahip ailelerin oran1 \%27.3 iken, 401-800 milyon TL. gelir elde eden orta gelir düzeyindeki ailelerin oran1 $\% 42.2 ; 801$ milyonun üzerinde gelir elde eden görece üst gelir gruplarındaki ailelerin oranı ise, \%30.6'dır. Araştırmada Türkiye'de yükseköğretimin kitleselleştiği ancak bu nicel büyümeden orta ve üst toplumsal sınıfların daha çok yararlanması nedeniyle, yükseköğretim sisteminin demokratikleşemediği vurgulanmıştır.

Yükseköğretimin finansmanında harç uygulamalarının gerekliliğini belirten görüşler de bulunmaktadır. Kesik (Akt. Tural, 2002,242) yaptığ 1 çalışmada yükseköğretimden görece orta ve yüksek gelirli aile çocuklarının daha fazla yararlandığı ifade edilerek, sembolik düzeyde de olsa öğrenim harc1 konulması gerektiği savunulmuştur. Benzer şekilde Akalın (1980) üniversite önündeki yığılmaları önlemek için yükseköğretimde "yararlanan ödesin" şeklindeki liberal ilkenin uygulanmasının doğru olacağını ifade etmektedir. Değerlendirmelerimizin çıkış noktası olarak eğitimin bir hak olduğunun temel alınması durumunda, sorun olarak tanımlanan yüksek düzeyli bir yükseköğretim talebinin aslında arzu edilen bir sonuç olduğu gözlenecektir. Bu durumda eğitim görmek isteyen insanların sayısının fazla oluşunun değil yükseköğretim talebinin karşılanamamasının bir sorun olarak düşünülmesi gerekir.

\section{Ekonomide Maliyet Kavramı}

Maliyet kavramının önemi üretim fonksiyonunda açıkça ortaya çıkmaktadır. Üretim fonksiyonu, üretim teknolojisi veri iken, zaman birimi başına kullanılacak belirli girdi miktarları ile elde edilecek azami ürün miktarları arasındaki ilişkidir (Türkay, 1996,80). Üretim için kullanılacak girdi değeri maliyeti oluşturmaktadır.

Ertek $(2005,1719)$ maliyetle ilgili olarak üç temel kavramı ele almaktadır. Bunlar "açık maliyetler", "örtük maliyetler" ve "ekonomik maliyet" 'tir. Muhasebe maliyetleri (accounting costs) diye de adlandırılan açık maliyetler (explicit costs), bir firmanın üretim ile ilgili olarak firma sahipleri dışında kaynaklarını kullandığı kişi veya firmalara yaptığı doğrudan ödemelerdir. Emek, makine, ham madde ve ara mal gibi girdiler için firmanın kasasından çıkan paraların toplamı açık maliyeti oluşturur. Örtük maliyetler (implicit costs), firma sahiplerinin firmanın üretimi için 
kullandıkları kendi kaynaklarının firsat maliyetlerinden oluşur. Bir ara malını veya bir üretim faktörünü bir malın ya da hizmetin üretiminde kullanabilmek için, başka bir mal veya hizmetin üretiminde kullanmaktan vazgeçmek gerekir. İşte, vazgeçilen bu üretimin değeri, söz konusu aramalı veya üretim faktörüyle şu anda yapılmakta olan üretimin firsat maliyetidir. Türkay, (1996,112) alternatif maliyeti, bir şeyi elde edebilmek için vazgeçmek zorunda kaldığımız şey olarak ifade etmektedir. Ekonomik maliyet (economic costs) ise açık maliyetler ile örtük maliyetlerin toplamına eşittir (Ertek, 2005,171).

Maliyet fonksiyonunun matematiksel denklemi ise M1=Pt.T + Pc.C şeklinde kurulmaktadır (Yiğitbaşı, 1996,147). Burada;

$$
\begin{aligned}
& \mathrm{M} 1=\text { Toplam maliyet } \\
& \mathrm{Pt}=\text { =̇şgücünün fiyatı (ücret) } \\
& \mathrm{T}=\text { İşücü miktarı } \\
& \mathrm{Pc}=\text { Sermayenin fiyatını (faiz), } \\
& \mathrm{C}=\text { Sermaye miktarını göstermektedir. }
\end{aligned}
$$

Yukarıdaki denklemden anlaşılacağı gibi toplam maliyet ile bu maliyetin üretilmesine imkan vereceği mal miktarı arasında bir ilişki kurulmaktadır.

$\mathrm{Bu}$ ilişkiye dayalı olarak, bir işletmenin maliyetleri ile ürettiği mal miktarı arasındaki matematiksel bağıntıları gösteren fonksiyonlara maliyet fonksiyonları denir (Bulmuş.1998:175). Maliyet fonksiyonu ifadesi, maliyetin bağımlı, üretimin ise açıklayıcı (bağımsız) değişken olduğu bir fonksiyonel bağıntıyı işaret eder (Bulmuş,1998,175).

\section{Eğitim Maliyeti}

"Eğitim maliyeti", bireyin eğitimi için yapılan dolaylı ve dolaysız, bireysel ve toplumsal harcamalar, vazgeçme maliyetinin toplamı ile bu öğrenimden dolayı bireyin sağlayacağı fazla ücret ve emekli aylıklarında alacağ fazlalıklar gibi ilerdeki toplam kazançları ve üretime yapılacak fazla katkıları karşılaştırarak "verimliliği" tahmin etmek için uygulanan klasik bir ekonomik çözümleme olarak gösterilmektedir (Adem, 1993,127).

J. Hallak'a (Akt, Adem, 1977,88) göre eğitimin topluma maliyeti tanımından şu eşitlik ortaya çıkmaktadır: Eğitim Maliyeti=Kamusal ve özel eğitim harcamaları (çift saymadan arınmış olarak)+ vazgeçme maliyetleri. 
Hallak $(1974,8)$ yapılacak maliyet çözümlemelerinin:

a)Eğitimin mali yönlerinin çözümlenmesinde teşhis olarak;

b)Eğitim sistemlerinin gelişme projeksiyonlarında hesaba katılan sayısal değerler olarak (tahmin) yararlanılabileceğini ve kullanılma alanlarına göre de yaklaşım yöntemlerinin değişebileceğini belirtmektedir.

Hallak (1974,8-21), yapılacak çözümlemeleri de iki grupta incelemektedir. Bunlardan ilki "makro çözümleme"dir. Makro çözümleme, eğitime ayrılan harcamaların zamansal evrimi yolu ile bilgi edinmedir. Hallak burada Federal Almanya'nın 1952-1962 yılları arasındaki eğitim harcamalarının cari ve sabit fiyatlarla harcama miktarlarını örnek göstermiştir. $\mathrm{Bu}$ analiz, mali kaynakların gelişimi hakkında ipuçları vermektedir.

Maliyet çözümlemesinde Hallak'ın kullandığı ikinci analiz "ayrıntılı çözümleme" dir. Bu analizde, eğitim tipine göre (örneğin kamusal eğitimözel eğitim) maliyet hesaplamaları, öğretim düzeylerine göre harcamalar ve birim maliyetlerinin analizi, kapsama göre maliyetler (maliyet türlerine göre, personel, donatım, genel yönetim giderleri vb.) belirtilmektedir.

\section{Eğitim Maliyetinin Çeşitli Sınıflandırmaları}

Eğitim maliyeti sınıflandırılırken temel olarak ekonomideki maliyet sınıflandırmaları esas alınmaktadır. Adem (1993,129-139) eğitim maliyetlerini sınıflandırırken harcamayı esas almıştır. Buradan yola çıkılarak kişisel harcamalar ve kamusal harcamalar ile bu iki harcamanın toplamı ve vazgeçme maliyetinin de eklenmesiyle toplumsal maliyete ulaşılmaktadır.

Kişisel Harcamalar. Bireysel maliyetler, öğrenim maliyeti, vazgeçme maliyeti ve yaşam maliyetlerinden oluşmaktadır. Öğrenim maliyetlerinin kapsamına öğrenim harcı, ders kitapları defter ve kırtasiye giderleri, okul giysisi için yapılan harcamalar ile bağışlar girmektedir (Tural, 2002,114, Ünal, 1996,237). Kitap ve diğer araç ve malzemeler, ulaşım giderleri, kurumlara yapılan öğrenci ödemeleri (öğrenim ve kayıt bedelleri), eğitimi sürdürebilmek için sağlanan konut ve benzerleri için yapılan ödemeler kişisel eğitim harcamalarıdır.

Kamusal Harcamalar.-Kamusal harcamalar, eğitim ve yetiştirme hizmetinin sunulması için devletin yüklendiği harcamalar olarak görülmektedir (Tural, 2002,114). Toplam eğitim harcamalarının belirleyicisi, öğretmenlerin ücretlerinin düzeyi olarak görülmektedir. Bu harcamalar, eğitim hizmetinin emek-yoğun bir üretim süreci olması nedeniyle devlet tarafından vergi, borç ve diğer kamu gelirlerinden karşılanan harcamalardır 
(Coombs ve Hallak, 1987, Akt. Ergen, 1999:9). Bu kapsamda öğretmen, yönetici, denetmen, eğitim uzmanı ve eğitimci olmayan personelin ücretleri, işletme ve bakım giderleri (elektrik, su, doğal gaz, posta, telefon, boya, temizlik malzemesi, kırtasiye, benzin gibi ) eğitim araçları, bina ve ek tesislerin yıllık kiraları yer alabilir (Tural, 2002,114).

Kamusal harcamalar eğitim harcamalarının en büyük bileşeni olduğu için kendi içinde birçok farklı sınıflandırmaya tabi tutulmuştur. Bu farklı sınıflandırmalar, kamusal harcamaların analizini kolaylaştırıp çeşitlendirmektedir. Adem (1993,130-132) kamusal maliyetleri harcamaların niteliğine göre de sınıflandırmıştır. Bunlar, yatırım giderleri, işletme giderleri maliyeti ve transfer harcamalarıdır. Adem $(1993,132)$ 'in Nguyen Huu Chau' dan yararlanarak ortaya koyduğu "özendirme maliyeti” kavramı transfer harcamaları ile aynı içeriğe sahiptir.

a)Yatırım Giderleri Maliyeti: Yatırım giderleri maliyeti okul binaları arsalarını kamulaştırma ya da arsa alımı, plan proje, bina yapımı, donatım ve büyük onarım giderleri oluşturmaktadır. Yatırım maliyeti, eğitime sürekli yararlanılabilecek sabit sermaye malları kazandırmaktadır. Bir yıldan daha uzun süre kullanılan ve bu yüzden ancak yıllar sonra yenilenmesine gereksinme duyulan mal ve hizmetlerin satın alınması için yapılan ödemeler, yatırım harcamalarını oluşturmaktadır. Yine uzun yıllar kullanılacak olan yatırım mallarının ömrünü uzatan büyük bakım ve onarımlar da yatırım harcamaları içinde değerlendirilmektedir (Tural, 2002,121). Hallak $(1974,31)$ amortisman paylarının cari harcamalar içinde yer almasının daha mantıklı olacağını savunmaktadır. Niteliği gereği amortisman payları yıllık olarak hesaplanmaktadır. Yıllık bir harcama olmasi nedeniyle cari harcamaların içinde yer alması gerektiği düşünülmektedir.

b)İşletme Giderleri Maliyeti: İşletme giderleri maliyeti deyiminden, cari ya da olağan harcamalar anlaşılmaktadır. Başlıca bölümleri aylık, tazminat, ek ders ücreti, demirbaş eşya ve kırtasiye, yardımcı hizmet, işletme, bakım, toplumsal yardım vb. giderlerden oluşur. İşletme giderleri açısından dikkat edilecek nokta, harcamaların kısa vadede kullanılan, yararları genelde mali yıl içinde ortaya çıkan ve bu süre içinde yinelenen ödemelerdir (Tural, 2002,120).

c) Transfer Harcamaları: Transfer harcamaları cari ve yatırım harcaması kapsamına girmeyen ve parasal kaynakların bir kısmının belli kurum ve kişilere aktarımını ifade eder (Tural, 2002:121). Burada amaç öğrencilere öğrenimlerini sürdürmelerini sağlamaktır. Öğrenci muayene ve tedavi, boş zamanı değerlendirme, kültürel ve sportif etkinlikler, öğrenci dernek, kantin ve yurtlarına yapılan yardımlarla, burs, kredi, vb. yardımlar bu kapsamda incelenebilir (Adem, 1993,132). 
Eğitim harcamaları içinde yatırım harcamaları ve cari harcamalarının oranları ve bu oranlarda zaman içinde gözlenen göreli değişmeler, eğitime ayrılan kaynakların, ne ölçüde yeni eğitim olanakları yaratma yönünde kullanıldığını, bu konudaki eğilimlerin ne yönde değiştiğini gösterebilmektedir (Ünal, 1996,239).

\section{Vazgeçme Maliyeti}

Eğitimin girdileri para ya da eğitim sürecinde kullanılan öğretmen ve diğer görevliler öğrencilerin zamanı, kitaplar, ders araç ve gereçleri ve binalar gibi gerçek kaynaklar cinsinden ölçülebilir. Bütün bu kaynakların alternatif kullanımı söz konusu olabilir. Eğitim amacıyla kullanılmamış olsalardı bir diğer etkinlik için kullanılacakları ve kaynakların sınırlı olduğu sayıltısından hareketle bu kaynakları kullanmanın alternatif yollarının feda edilmesi ya da bunlardan vazgeçilmesi gerektiği düşünülmektedir (Woodhall, 1987, 259). Böylece vazgeçme maliyeti altenatif kullanma olasılığının sınırsızlığı ve kaynakların sınırlılığına dayalı bir analiz değeri olarak ortaya çıkmaktadır.

Vazgeçme maliyeti (firsat maliyeti veya alternatif maliyet), kaynakların en kârlı kullanımında elde edilmesi beklenen parasal değerdir (Woodhall, 1987, Akt. Ergen, 1999,12). Bu durum şu şekilde betimlenebilmektedir. "Birey öğrenimini sürdürmeyip çalışmaya başlamış olsaydı, kendisine gelir sağlayabilirdi. İşe başladığı günden itibaren gerek emeklilik, gerek terfilerine esas olma üzere derece almaya başlayacaktı. Öğrenimini sürdürmekle bazı kazançlardan vazgeçmiş oluyor. İşte hem toplumun hem bireyin uğramış olduğu gelir kaybına vazgeçme maliyeti denilmektedir" (Adem 1993,140).

Bottomley $(1972,20-22)$ vazgeçme maliyetini ölçerken öncelikle eğitim faktörlerini sınıflandırarak her biri için fırsat maliyeti hesaplamıştır. Sınıflandırmada eğitim binasının, büyük sermaye gerektiren ekipmanların, öğretim kadrosu ve diğer çalışanların, öğrencilerin zamanlarının, eğitim araç ve gereçlerinin vazgeçme maliyetleri ayrı ayrı değerlendirilmiştir. Eğitimin sürdürüldügü bina/binaların firsat maliyetini bu bina/binaların kira gelirleri üzerinden belirlemiş, benzer şekilde büyük sermaye gerektiren ekipmanların vazgeçme maliyetini de başka bir kuruma verilmesi halinde getireceği kira gelirleri ile değerlendirmiştir.

Schultz (1960, Akt. Adem, 1993,144) öğrencilerin vazgeçme maliyetinin belirlenmesi için nüfus istatistiklerinin de yardımıyla belirli yaş kümeleri için, sanayide çalışan işçilerin günlük, haftalık ücretlerinden yola çıkarak, ortaöğretim ve yükseköğretim öğrencileri için ayrı ayrı firsat maliyeti hesaplamıştır. Buna göre ortaöğretimdeki bir öğrencinin kazanç kaybının sanayide çalışan bir işçinin 11 haftalık gelirine, yükseköğretimde 
de 25 haftalık gelir kaybına eşit olacağı hesaplanmıştır. Türkiye'de yapılan araştırmalarda da Schultz'un izlediği yolun takip edildiği görülmektedir. DPT'nin 1989'da yaptığı araştırmada, Akalın tarafından 1980'de yapılan araştırmada, Tek (1987) tarafından yapılan fayda maliyet analizinde üniversite öğrencisinin vazgeçme maliyeti için lise mezunu bir işgücünün asgari ücreti düzeyi esas alınmıştır.

Tural $(2002,118)$ Türkiye'de vazgeçme maliyeti için yapılan yordamanın iki türlü olacağını ifade etmiştir. Buna göre DPT tarafindan yapılan araştırmada olduğu gibi, asgari ücretli ve öğrencilerin çalışıp bir gelir elde edebilecekleri halde öğrenimleri nedeniyle çalışamadıkları ayları dikkate alıp hesaplanan geliri, ilgili yaş grubu işsizlik oranı ile düzeltmektir. İkincisi ise, özellikle ortaöğrenim yaş grubu öğrencilerinin aday çırak ya da işletmelerde meslek eğitimi gören öğrenci statüsünde çalışma yaşamına girip bir gelir elde edeceği varsayımına dayalı olarak 3308 sayılı Çıraklık ve Meslek Eğitimi Yasasının 25. maddesine istinaden gelir kaybını hesaplamaktır. $\mathrm{Bu}$ maddeye göre, en az gelir kaybına asgari ücretin \% 30'undan hareketle ulaşılabilir. Birinci yaklaşım gelir kaybının varsayıma dayalı üst sınırını, ikinci yaklaşım ise alt sınırını yordamaya yardımcı olmaktadır. 3308 sayılı Çıraklık ve Meslek Eğitimi Yasası, 4702 sayılı yasa ile 2001 yılında bazı maddeleri kanun koyucu tarafından değiştirilmiştir. Burada sözü edilen 25. maddenin bir değişikliğe uğramadığı görülmüsstür.

Ĕ̆itim Maliyetlerinin Bütün Üretim Düzeyine Göre ve Birim Üretim Düzeyine Göre Sınıflandırılması

Çalışmanın bu kısmında eğitim maliyetleri alanyazında belirtilen toplam maliyet, toplam sabit maliyet, toplam değişken maliyet başlıkları altında eğitim sürecinin bütünü düşünülerek incelenmektedir. Birim üretim başına maliyet sınıflandırması kapsamında birim maliyet, ortalama maliyet, ortalama sabit maliyet, ortalama değişken maliyet, marjinal maliyet kavramları açıklanmaktadır.

\section{Eğitim Sürecinin Bütününe Göre Maliyetler}

Toplam Maliyet, eğitim sürecinde kullanılan bütün girdilerin toplam parasal değerini ifade etmektedir. Tural $(2002,122)$, toplam maliyetin hesaplanmasında alanyazında farklı uygulamalar olduğunu ifade etmektedir. Bazı çalışmalarda toplam maliyet sadece cari maliyetlere karşılık gelecek biçimde kullanılırken, bazılarında ise yatırım maliyetleri de bu kapsama alınmaktadır. Ekonomideki toplam maliyet kavramı üretim sürecinde kullanılan bütün kaynakları bu hesabın içine almaktadır. Toplam maliyet, verili sayıda öğrenciye eğitim hizmeti sunulması için yüklenilmesi gereken bütün maliyetlere karşılık gelir. Kamu harcamaları açısından ele alındığında 
toplam harcamalar verili bütçe dönemindeki cari, yatırım ve transfer harcamalarının toplamını ifade eder. Bu harcamalar ilgili mali y1lın kesin hesaplarından elde edilir ve bütçeye konulan başlangıç ödenekleriyle aralarında önemli büyüklükte farklılıklar olabilir (Ergen, 1999,16). Toplam maliyet toplam sabit maliyet ve toplam değişken maliyetin toplamından oluşmaktadır.

a) Toplam Sabit Maliyet. Tural $(2002,121)$ sabit maliyetlerin, eğitim sisteminin belli nitelikte eğitim verebilmesi için her zaman yüklenilmesi gereken bina maliyeti, asgari ücret ödemeleri, mobilya, ekipman, 1sınma maliyeti gibi harcamaları içerdiğini ifade etmektedir. Sabit maliyetlerin önemli bir kısmını sabit sermaye maliyetleri oluşturmaktadır. Toplam sabit maliyet ekonomide kısa dönem göz önünde bulundurularak tanımlanan bir maliyettir. Toplam sabit maliyet eğitim sisteminin, hiçbir öğrenci yetiştirmese dahi katlanacağı yani üretimin sıfır olması halinde bile katlanmas1 gerekli maliyetleri ifade etmektedir. Türkay (1996,115), tesisin bakılması, korunması için yapılması gerekenler ile, sözleşmeden doğan giderleri de sabit maliyetlerin içinde saymıştır.

b) Toplam Değiş̧ken Maliyet. Değişken maliyetler üretim düzeyine doğrudan bağlıdır ve eğitm kesimi açısından öğrenci ve mezun sayısından etkilenen öğretmen ücretleri, sınıflarda kullanılan araç ve gereçler, ders kitapları giderleri gibi harcamaları içermektedir. Öğrenci sayısı arttıkça ya da öğrenim süresi uzadıkça değişken maliyetler yükselir (Tural, 2002). Üretim düzeyi sıfır olursa değişken maliyetler de sıfır kabul edilmektedir. Çünkü ekonomide değişken maliyet tamamen üretim düzeyine göre belirlenmiş maliyet türüdür.

\section{Birim Üretim Düzeyine Göre Eğitim Maliyetleri}

a) Birim Maliyet. Bir öğrencinin eğitiminden doğan maliyete birim maliyet denilmektedir (Tural, 2002,123). Birim maliyet, inceleme konusu eğitim düzeninin etkililiğini, eğitim kesiminde kullanılan üretim etmenlerinin birbirleriyle ilişkili olarak kullanılış biçimini, yeni eğitim yöntem tekniklerinin mali açıdan üstünlük ve sakıncalarını değerlendirmeye izin vermektedir. Böylece maliyet çözümlemesi, olası seçenekler göz önünde tutularak gelecek yıllardaki harcamaların kestirilmesinde eğitim planlamasında temel araç olarak kullanılmaktadır (Adem, 1993,128). Tural $(2002,123)$, birim maliyetlerin farklı şekillerde hesaplanabileceğini ifade etmektedir. Ortalama maliyet ve marjinal maliyet hesaplamaları birim maliyetin içinde ifade edilebilecek ölçümlerdir. Seçilen birime ve harcama alanına dayalı olarak çeşitli birim maliyet tanımlamalarına ulaşılabilir (Hallak, 1974, Akt. Ergen, 1999,45): 
1-Öğrenci başına maliyet, 2-Mezun başına maliyet, 3-Ders saati başına maliyet, 4-Yatılı öğrenci başına maliyet, 5-Öğretmen başına maliyet, 6-Okul ya da okul bölgesi başına maliyet

b) Ortalama Maliyet. Ortalama maliyet, toplam maliyetin eğitim gören öğrenci sayısına bölünmesi ile bulunmaktadır. Burada dikkati çeken bir nokta genellikle çıktı olarak öğrencilerin ele alınmasıdır. Oysa üniversiteler sadece öğrenci yetiştiren değil aynı zamanda araştırma, danışmanlık gibi hizmetler de üretmektedirler. $\mathrm{Bu}$ ürünlerin maliyetlerini birbirinden ayrıştırmak güçtür, zira birbirlerini besleyen süreçlerdir. Aynı eğitim kurumu içinde yürütülen farklı etkinliklerin ayrıştırılamaması, bu etkinliklerin doğurduğu maliyetlerin "ortak maliyetler" olarak ele alınmasını gerektirir (Very, 1987, Akt. Tural, 2002,124).

c) Marjinal Maliyet. Öğrenci sayısı çıtı olarak alındığında, öğrenci sayısı arttıkça, en son öğrenci artışıla birlikte toplam maliyette meydana gelen değişme marjinal maliyet kavramıla ifade edilir (Ünal, 1996,239; Tural 2002, 123).

Alanyazında yapılan araştırmalara bakıldığında ülke bazında ve yükseköğretimin bütününü değerlendiren, araştırmalar da bulunmaktadır. Eide'nin (1969) DPT için yaptığ 1 "Türk Yükseköğretiminin Maliyet Yapısı" isimli araştırma, bu alanda yapılmış kapsamlı araştırmalardan biridir. Çalışmada fen mühendislik, sağlık vb. programların ayrı ayrı maliyet analizi yapılmıştır. Karakütük'ün (1991,817-820), mesleki eğitimin verimliliğini incelediği araştırmada da, öğrenci başına birim cari harcamaları hesaplamıştır. Karakütük $(1991,817)$, araştırmasında verimliliği kavramsal olarak belirtmiş ve bu belirlemelere göre, ekonomik anlamda verimliliği sağlayabilmek için, en az girdi ile en çok çıktıyı -niteliği düşürmeden hatta artırarak- elde etmek gerektiğini ifade etmiştir. Aksoy (1991) ise 1976-1985 yılları arasındaki, lise düzeyindeki mesleki eğitim kurumlarının yatırım projelerinin gerçekleşme maliyet ve düzeylerini belirlediği araştırmada, yatırım projelerinin (okul binalarının inşası) cari ve sabit fiyatlarla maliyetlerini hesaplamıştır. Aynı araştırmada, yürütülen projelerin gerçekleşme düzeyleri ve öngörülen maliyet ile gerçekleşme maliyetleri karşılaştırarak farklılıklar üzerinden değerlendirmeler yapılmıştır. Araştırma sonucunda, mesleki eğitime yapılan yatırımların büyük oranda öngörülen maliyetlerin çok üstünde olduğu ve zamanında bitirilen projelerin oranlarının ise ancak \% 7 düzeyinde kaldığı belirlenmiştir.

$\mathrm{Bu}$ çalıșmada ise makro düzeydeki araștırmaların sonuçlarının ortaya koyduğu ve günlük yaşamdaki etkileri yoluyla da gözlenebilen yükseköğretimin finansmanı konusunda izlenen politikalardaki değişimlerin, üniversitelerin temel birimleri olan fakülteler boyutunda hangi düzeylerde hissedildiği Ankara Üniversitesi Eğitim Bilimleri Fakültesi örneği üzerinden ele alınmıştır. 


\section{Amaç}

$\mathrm{Bu}$ araştırmanın amacı, yükseköğretim finansmanında yaşanan değişmeler bağlamında, Ankara Üniversitesi Eğitim Bilimleri Fakültesi'nde sürdürülen lisans eğitiminin özel ve kamusal maliyetinin belirlenmesi ve çözümlenmesidir. $\mathrm{Bu}$ amaçla Ankara Üniversitesi Eğitim Bilimleri Fakültesi'nde 1990-2005 yılları arasında yapılan cari, transfer ve yatırım harcamaları, öğretim elemanı ve öğrenci sayılarındaki değişmeler, öğrenci başına ve mezun başına düşen öğrenci harcamaları, öğrencilerin kredi ve burs gibi mali destekleri ne düzeyde aldıkları, öğrencilerin firsat maliyeti hakkındaki düşünceleri, öğrencilerin eğitim nedeniyle veya eğitimleri süresinde ortaya çıkan harcamaları ne düzeyde karşılayabildikleri, eğitimlerini sürdürürken mali sıkıntılarının olup olmadığ sıkıntılar yaşıyorlarsa bunların nedenleri üzerine görüşleri araştırılmıştır.

\section{YÖNTEM}

Çalışma kapsamında Ankara Üniversitesi Eğitim Bilimleri Fakültesi'nin kamusal harcamalarının belirlenmesi için 1990-2005 yılları arasındaki Bütçe Kesin Hesap Cetvellerinde yer alan cari, yatırım ve transfer harcamaları belirlenmiştir. Cari (nominal) değerler olarak belirlenen harcama miktarlarının karşılaştıılabilip, yorumlanabilmesi için TÜIKK tarafından belirlenen TÜFE ve TEFE rakamlarına göre sabit fiyatlara çevrilmiştir. Bunun yanında 2005 yılında Yeni Türk Lirası uygulamasına geçildiği için bu harcama miktarları Yeni Türk Lirası (YTL) olarak ifade edilmiştir.

1990-2005 yılları arasında yapılan kamusal harcamaların zaman içindeki gelişim sürecinin belirlenmesinde doğrusal kalıp (yarı logaritmik kalıp) kullanılmıştır. Doğrusal Kalıp Ertek (1996,145-147) tarafından şöyle açıklanmaktadır: "Y ve X değişkenleri ile ilgili verilerden biri aritmetik, diğeri geometrik seri özelliği taşıdığında yarı logaritmik kalıp kullanmak yerinde olur. Yarı logaritmik kalıp iki türdedir. Birinde y geometrik $\mathrm{x}$ aritmetik seriler durumunda, diğerinde $\mathrm{y}$ aritmetik $\mathrm{x}$ geometrik seriler durumundadır. Y'nin geometrik, $X$ 'in aritmetik dizi olduğu durumlarda $\mathrm{Y}=\mathrm{a} . \mathrm{b} \times$ olarak ifade edilebilir. Bunun da logaritması alındığı zaman; $\log Y^{1}=\log a+x \log b$ olur.

$\mathrm{Bu}$ araştırmada $\mathrm{x}$ zamanı, yani aritmetik serileri, y ise harcamaları yani geometrik artışı gösteren değişken olarak değerlendirilmiş, buna göre yarı logaritmik kalıp kullanılmıștır. Yarı logaritmik kalıp kullanıldığında harcamalardaki artışın düzeyini belirlemek için başlangıç yılı ve incelenen son yıl yardımı ile trend doğrusu çizilmektedir. Kural olarak harcamalarda 
azalış olan durumlarda trend doğrusu çizilmemektedir. Araştırmada, artış olan harcamaların trend denklemlerine ve trend doğrularına yer verilmiş, ancak azalış olan dönemlerin trend denklemi verilmiş, trend doğrusu çizilmemiștir. $\mathrm{Bu}$ doğrultuda, araștırmada trend doğrusunun belirlenmesi için 1990 yılı ve 2005 yılı temel alınmıştır. $Y^{1} 1990$ dönem baş1 noktası $\mathrm{Y}^{1} 2005$ ise dönem sonu noktasını oluşturmaktadır. Bu durumda;

$$
\begin{aligned}
& Y^{1} 1990=\log a+x \log b \\
& Y^{1} 2005=\log a+x \log b \quad \text { denklemlerine ulaşılmaktadır. }
\end{aligned}
$$

Öğrenci sayıları, mezun sayıları ve öğretim elemanı sayıları 1990-2005 yılları arasındaki ÖSYM yükseköğretim İstatistiklerinden elde edilmiştir. Öğrenci sayılarının gelişiminin yarı logaritmik incelemesinde Adem $(1977 ; 1981)$ ve Aksoy'un (1991) çalışmalarında da kullanılan grafik çizimi yönteminden yararlanılmıştır.

Öğrencilerin kişisel eğitim harcamaları, bu harcamaları karşılama düzeyleri ve kaynakları ile alternatif maliyetin (firsat maliyeti) belirlenmesi ve hesaplanmasını sağlayacak veri toplama aracı geliştirilmiştir. Bu aracın uygulanması sonucu elde edilen verilerle öğrencilerin yıllık kişisel eğitim harcamalarına ve alternatif maliyet miktarlarına, ve eğitim maliyeti ile ilgili konulardaki görüşlerine ulaşılmıştır. Elde edilen harcama miktarlarının analizi ile kamusal, kişisel, firsat maliyeti ve toplumsal maliyet miktarlarına ulaşılmıştır.

\section{Çalışma Evreni ve Örneklem}

Araştırmanın çalışma evrenini, Ankara Üniversitesi Eğitim Bilimleri Fakültesi'ne devlet tarafindan yapılan kamu harcamaları ve 2005-2006 öğretim y1lında kayıtlı öğrenciler oluşturmaktadır. Öğrenci harcamalarının belirlenmesinde 2005 yılı temel alındığı için birinci sınıf öğrencileri çalışma evrenine dahil edilmemiştir. Öğrenci sayıları, öğretim üyesi ve öğretim görevlileri sayılarındaki artışlar ortaya konularak zaman içindeki artış ve azalış değerlendirilmiştir. Araştırmanın çalışma evreninde yer alan öğrenci sayısı, örneklem grubu ve araştırmaya katılan öğrenci sayısı bölümler itibariyle Çizelge 1'de verilmiştir. Çizelge 2'de ise sınıflara göre araştırma evren ve örneklem sayıları belirtilmiştir. 
Çizelge 1. Bölümlere Göre Araştırma Alt Evreni ve Örneklemi

\begin{tabular}{|c|c|c|c|c|}
\hline Sinıflar & Mevcut Öğrenci Sayısı & $\begin{array}{l}\text { Araştırmaya } \\
\text { Öğrenci Sayısı }\end{array}$ & Katılan & $\%$ \\
\hline 2. Sinıf & 421 & 202 & & 48 \\
\hline 3. Sinıf & 377 & 194 & & 51 \\
\hline 3. Sinıf & 385 & 240 & & 62 \\
\hline Toplam & 1183 & 636 & & 54 \\
\hline
\end{tabular}

Çizelge 2. Sinıflara Göre Araştırma Evreni ve Örneklemi

\begin{tabular}{lccc}
\hline Program Adı & $\begin{array}{c}\text { Mevcut Öğrenci } \\
\text { Sayısı }\end{array}$ & $\begin{array}{c}\text { Araştırmaya } \\
\text { Katılan Öğrenci } \\
\text { Sayısı }\end{array}$ & $\%$ \\
\hline Sınıf Öğretmenliği & 268 & 167 & 62 \\
\hline $\begin{array}{l}\text { Sosyal Bilgiler } \\
\text { Öğretmenliği }\end{array}$ & 165 & 92 & 56 \\
\hline $\begin{array}{l}\text { Okul Öncesi } \\
\text { Öğretmenliği }\end{array}$ & 165 & 86 & 56 \\
\hline BÖTE & 142 & 58 & 41 \\
\hline PDR & 231 & 96 & 42 \\
\hline Z.E. Öğretmenliği & 212 & 135 & 64 \\
\hline Toplam & 1183 & 636 & 54 \\
\hline
\end{tabular}

Araştırma evrenini; birinci sınıflar dışındaki bütün Eğitim Bilimleri Fakültesi öğrencileri oluşturmaktadır. Alınması gerekli örneklem büyüklüğü \% 1'lik güven aralığına göre belirlenmiştir. Araştırmada belli bir düzeyde eksik dönüş olacağ 1 varsayılarak uygulamaya gidilmiş ancak yüksek dönüş düzeyi nedeniyle hesaplanan örneklem grubunun üzerinde öğrenci sayısına ulaşılmıştır. Eğitim Bilimleri Fakültesi'ni daha iyi temsil edeceği ve yanlı bir dağılım oluşturmadığı gözlenerek uygun bir şekilde doldurulan bütün anketler değerlendirilmeye alınmıştır.

Mevcut öğrenciler ve araştırmaya katılanların cinsiyete göre dağılımı çizelge 3'te verilmiştir. Cinsiyet açısından kadın ve erkek öğrencilerin temsil düzeylerinde her iki yönlü \% 6 düzeyinde bir sapma olmuştur. Ancak bu düzeyde bir farkın verilerin anlamlandırılmasında sistematik bir yanlılığa yol açmayacağ düşünülmüştür. 
Çizelge 3. Öğrencilerin Cinsiyete Göre Dağılımları

\begin{tabular}{llllll}
\hline Cinsiyet & $\begin{array}{l}\text { Mevcut Öğrenci } \\
\text { Sayısı (a) }\end{array}$ & \% & $\begin{array}{l}\text { Araştırmaya Katılan } \\
\text { Öğrenci Sayısı (b) }\end{array}$ & $\begin{array}{l}\text { \% } \\
\text { (b) }\end{array}$ \\
\hline Kadın & 763 & 64 & 436 & 70 \\
\hline Erkek & 420 & 36 & 189 & 30 \\
\hline Toplam & 1183 & 100 & 625 & 100 \\
\hline
\end{tabular}

\section{BULGULAR VE YORUM}

\section{Kamusal Harcamalar}

Ankara Üniversitesi Eğitim Bilimleri Fakültesi'nin kamusal harcama miktarları, cari, yatırım, transfer harcamaları ve Rektörlük idari hizmetleri ve Kütüphane ve Araştırma Giderlerinden Eğitim Bilimleri Fakültesi'ne düşen pay Çizelge 4'de gösterilmiştir. Her bir harcama kaleminin zamansal gelişimleri yarı logaritmik kalıp yardımı ile belirlenmiştir. Buna göre Eğitim Bilimleri Fakültesi'nde cari harcamalar 1990-2005 yılları arasında yıllık ortalama $\% 5$ oranında azalma göstermiştir. Yatırım harcamaları yıllık ortalama \% 5,1 oranında artış göstermiştir. Transfer harcamalarının ise \% 4,4 oranında artış gösterdiği görülmüştür. Araştırma kapsamında ayrıca ele alınan personel harcamalarının ise \% 1,4 oranında azaldığı gözlenmiştir.

Çizelge 4. A. Ü. Eğitim Bilimleri Fakültesi Cari, Yatırım, Transfer Harcamaları (1990-2005 Yılları; 2005=100)

\begin{tabular}{cccccc}
\hline Yıllar & $\begin{array}{c}\text { EBF Cari } \\
\text { Harcamaları }\end{array}$ & $\begin{array}{c}\text { EBF Yatırım } \\
\text { Harcamaları }\end{array}$ & $\begin{array}{c}\text { EBF } \\
\text { Transfer } \\
\text { Harcamaları }\end{array}$ & $\begin{array}{c}\text { Rektörlük ve } \\
\text { Kütüphane } \\
\text { Payı }\end{array}$ & Toplam \\
\hline $\mathbf{1 9 9 0}$ & $4.027 .071,68$ & $590.282,89$ & $454.067,59$ & $448.552,80$ & $5.519 .974,96$ \\
\hline $\mathbf{1 9 9 1}$ & $3.925 .794,06$ & $632.611,30$ & $593.894,07$ & $480.026,34$ & $5.632 .325,77$ \\
\hline $\mathbf{1 9 9 2}$ & $4.125 .001,49$ & $641.568,74$ & $1.110 .680,42$ & $454.874,71$ & $6.332 .125,36$ \\
\hline $\mathbf{1 9 9 3}$ & $4.413 .497,69$ & $1.069 .572,03$ & $803.409,12$ & $455.710,51$ & $6.742 .189,35$ \\
\hline $\mathbf{1 9 9 4}$ & $3.341 .462,56$ & $793.128,38$ & $676.871,56$ & $369.714,11$ & $5.181 .176,61$ \\
\hline $\mathbf{1 9 9 5}$ & $2.902 .257,85$ & $889.116,86$ & $721.310,04$ & $333.601,77$ & $4.846 .286,52$ \\
\hline $\mathbf{1 9 9 6}$ & $3.365 .766,12$ & $711.717,62$ & $952.908,55$ & $330.841,93$ & $5.361 .234,22$ \\
\hline $\mathbf{1 9 9 7}$ & $4.096 .809,38$ & $872.321,78$ & $881.600,45$ & $298.300,32$ & $6.149 .031,93$ \\
\hline $\mathbf{1 9 9 8}$ & $4.010 .776,12$ & $723.895,21$ & $844.370,43$ & $268.382,08$ & $5.847 .423,84$ \\
\hline $\mathbf{1 9 9 9}$ & $3.714 .901,70$ & $732.719,51$ & $1.070 .440,95$ & $329.397,94$ & $5.847 .460,10$ \\
\hline $\mathbf{2 0 0 0}$ & $3.349 .445,99$ & $897.394,25$ & $1.295 .659,08$ & $322.714,78$ & $5.865 .214,10$ \\
\hline $\mathbf{2 0 0 1}$ & $3.138 .903,63$ & $792.365,93$ & $1.182 .026,43$ & $369.440,71$ & $5.482 .736,70$ \\
\hline $\mathbf{2 0 0 2}$ & $3.533 .163,77$ & $1.309 .771,46$ & $1.315 .850,72$ & $476.457,23$ & $6.635 .243,18$ \\
\hline $\mathbf{2 0 0 3}$ & $3.697 .558,32$ & $995.994,37$ & $1.259 .616,46$ & $446.047,78$ & $6.399 .216,93$ \\
\hline $\mathbf{2 0 0 4}$ & $4.058 .374,58$ & $1.768 .992,03$ & $1.415 .960,25$ & $566.876,31$ & $7.810 .203,17$ \\
\hline $\mathbf{2 0 0 5}$ & $3.854 .636,53$ & $1.341 .150,17$ & $624.836,93$ & $614.766,32$ & $6.435 .389,95$ \\
\hline & & & & &
\end{tabular}


Çizelge 5'deki öğrenci başına maliyetin bulunmasında;

Öğrenci Başına Birim Harcama = Toplam Harcama Miktarı / Öğrenim Gören Öğrenci Saylsı

Çizelge 6'daki mezun başına maliyetin hesaplanması için;

Mezun Başına Maliyet = Toplam Harcama Miktarl / Mezun Olan Öğrenci Sayısı matematiksel ifadeleri kullanılmıştır.

Çizelge 5. A. Ü. Eğitim Bilimleri Fakültesi Birim Öğrenci Maliyeti (1990-2005 Y1llar1; $2005=100$ )

\begin{tabular}{cccc}
\hline Y1llar & $\begin{array}{c}\text { EBF Toplam } \\
\text { Harcamaları }\end{array}$ & $\begin{array}{c}\text { EBF Öğrenci } \\
\text { Sayısı }\end{array}$ & Birim Maliyet \\
\hline 1990 & $5.519 .974,96$ & 1274 & $4.332,79$ \\
\hline 1991 & $5.632 .325,77$ & 1307 & $4.309,35$ \\
\hline 1992 & $6.332 .125,36$ & 1344 & $4.711,40$ \\
\hline 1993 & $6.742 .189,35$ & 1458 & $4.624,27$ \\
\hline 1994 & $5.181 .176,61$ & 1497 & $3.461,04$ \\
\hline 1995 & $4.846 .286,52$ & 1421 & $3.410,48$ \\
\hline 1996 & $5.361 .234,22$ & 1322 & $4.055,40$ \\
\hline 1997 & $6.149 .031,93$ & 1126 & $5.460,95$ \\
\hline 1998 & $5.847 .423,84$ & 1134 & $5.156,46$ \\
\hline 1999 & $5.847 .460,10$ & 1192 & $4.905,59$ \\
\hline 2000 & $5.865 .214,10$ & 1356 & $4.325,38$ \\
\hline 2001 & $5.482 .736,70$ & 1561 & $3.512,32$ \\
\hline 2002 & $6.635 .243,18$ & 1586 & $4.183,63$ \\
\hline 2003 & $6.593 .119,00$ & 1605 & 3.987 .05 \\
\hline 2004 & $7.810 .203,17$ & 1605 & $4.866,17$ \\
\hline 2005 & $6.435 .389,95$ & 1598 & $4.027,15$ \\
\hline
\end{tabular}

Çizelge 5 incelendiğinde, sabit fiyatlarla birim maliyetin düştüğü gözlenmektedir. Ayrıca, 1990-2005 yılları arasında mezun başına maliyette dalgalanmalar yaşandığ 1 Çizelge 6'da görülmektedir. Çizelge 5'de verilen harcama miktarlarının zamansal gelişimlerinin yarı logaritmik kalıp çizimleri Şekil 1'de verilmiştir. 
Çizelge 6. A.Ü. Eğitim Bilimleri Fakültesi Mezun Başına Öğrenci Maliyeti $(1990-2005 ; 2005=100)$

\begin{tabular}{cccc}
\hline Yillar & Toplam Harcama & $\begin{array}{c}\text { Mezun } \\
\text { sayısı }\end{array}$ & $\begin{array}{c}\text { Mezun Başına Harcama } \\
\text { Miktarı }\end{array}$ \\
\hline 1990 & $5.519 .974,96$ & 238 & $23.193,17$ \\
\hline 1991 & $5.632 .325,77$ & 271 & $20.783,49$ \\
\hline 1992 & $6.332 .125,36$ & 198 & $31.980,43$ \\
\hline 1993 & $6.742 .189,35$ & 322 & $20.938,48$ \\
\hline 1994 & $5.181 .176,61$ & 259 & $20.004,54$ \\
\hline 1995 & $4.846 .286,52$ & 297 & $16.317,46$ \\
\hline 1996 & $5.361 .234,22$ & 337 & $15.908,71$ \\
\hline 1997 & $6.149 .031,93$ & 323 & $19.037,25$ \\
\hline 1998 & $5.847 .424,10$ & 275 & $21.263,36$ \\
\hline 1999 & $5.847 .460,10$ & 183 & $31.953,33$ \\
\hline 2000 & $5.865 .214,10$ & 146 & $40.172,70$ \\
\hline 2001 & $5.482 .736,70$ & 348 & $15.754,99$ \\
\hline 2002 & $6.635 .243,18$ & 365 & $18.178,75$ \\
\hline 2003 & $6.593 .119,00$ & 356 & $17.975,33$ \\
\hline 2004 & $7.810 .203,17$ & 379 & $20.607,40$ \\
\hline 2005 & $6.435 .389,95$ & 477 & $13.491,38$ \\
\hline
\end{tabular}

\section{Özel Harcamalar}

Araştırmada öğrencilerin kişisel eğitim harcamalarına geliştirilen veri toplama aracı (anket) ile ulaşılmıştır. Öğrencilerin aylık kişisel eğitim harcamaları kalemlerine göre şöyle bir dağılım göstermektedir: Barınma giderleri 165 YTL; beslenme 150 YTL; ulaşım 70 YTL; giyim harcamaları 54 YTL; eve gidiş-dönüş giderleri 38 YTL; ders kitabı vb 30 YTL; gezi tur etkinlikleri 25 YTL; mediko, öğrenci belgesi katkı payı vb harcamalar 21 YTL; ders dışı kitaplar 18 YTL'dir. Bu harcamaların aylık toplamı 620 YTL; yıllık 4.960 YTL olarak saptanmıştır. ;

Çizelge 7. Öğrencilerin Harcamalarını Karşılamak için Kullandıkları Kaynakları

\begin{tabular}{lll}
\hline Gelir Kaynakları & Öğrenci Sayısı & $\%$ \\
\hline Yalnızca ailem & 115 & 18,1 \\
\hline Yalnızca Burslar/Kredi & 75 & 11,8 \\
\hline Çalışarak & 5 & 0,8 \\
\hline Diğer Kaynaklar & 1 & 0,2 \\
\hline Ailem ve Burs Kredi & 438 & 69,1 \\
\hline
\end{tabular}




\begin{tabular}{lcc}
\hline Toplam & 634 & 100 \\
\hline
\end{tabular}

Öğrencilerin ailelerinden ortalama 349 YTL harçlık aldıkları görülmektedir.Harçlık miktarlarındaki standart sapmanın yüksek oluşu $(\mathrm{SS}=200,22)$ harçlık miktarındaki alt ve üst sınırların oldukça büyük olduğunu göstermiştir. Bu nedenle Çizelge 8 'de öğrencilerin aylık gelir aralıkları verilmiştir. Öğrencilerin \% 49,9'unun 201-400 YTL aras1 gelirlerinin olduğu görülmektedir.

\section{Çizelge 8. Öğrencilerin Aylık Gelir Aralıkları}

\begin{tabular}{lll}
\hline Gelir Aralı̆̆ı & Ö̈̆renci Sayısı & $\mathbf{\%}$ \\
\hline 100 YTL ve altı & 11 & 1,8 \\
\hline 101-200 YTL aras1 & 117 & 19,7 \\
\hline 201-300 YTL aras1 & 154 & 25,9 \\
\hline 301-400 YTL aras1 & 143 & 24 \\
\hline 401-500 YTL aras1 & 87 & 14,6 \\
\hline $501-600$ YTL aras1 & 32 & 5,4 \\
\hline $601-700$ YTL aras1 & 23 & 3,9 \\
\hline 700 ve üzeri & 28 & 4,7 \\
\hline Toplam & 595 & 100 \\
\hline
\end{tabular}

Çizelge 9'da öğrencilerin kredi ve burs alma durumlarının düzeyleri belirlenmiştir. Buna göre, öğrencilerin \% 75'i öğrenim kredisi almakta, \% 50'si katk1 kredisi almaktadır. Başka bir kurumdan burs/kredi alanların oran $1 \% 19,1$ 'dir.

\section{Çizelge 9. Kredi Burs Alma Durumu}

\begin{tabular}{|c|c|c|c|c|c|c|}
\hline $\begin{array}{l}\text { Kredi/Burs } \\
\text { Alma } \\
\text { Durumu } \\
\end{array}$ & Öğrenim & redisi & Katkı Kr & disi & $\begin{array}{l}\text { Başka } \\
\text { Kurumdan } \\
\text { Burs/Kred }\end{array}$ & $\begin{array}{ll} & \text { Bir } \\
\text { i } & \\
\end{array}$ \\
\hline & $\begin{array}{l}\text { Öğrenci } \\
\text { Sayısı }\end{array}$ & $\%$ & $\begin{array}{l}\text { Öğrenci } \\
\text { Sayısı }\end{array}$ & $\%$ & $\begin{array}{l}\text { Öğrenci } \\
\text { Sayısı }\end{array}$ & $\%$ \\
\hline Alan & 473 & 75,8 & 316 & 50,2 & 119 & 19,1 \\
\hline Almayan & 151 & 24,2 & 313 & 49,8 & 505 & 80,9 \\
\hline TOPLAM & 624 & 100,0 & 629 & 100,0 & 624 & 100,0 \\
\hline
\end{tabular}

Öğrencilerin eğitimlerini sürdürmek için ek iş yapmak durumunda kalıp kalmadıkları sorgulanmıştır. Buna göre öğrencilerin \% 79'unun herhangi bir işte çalışmadığ 1 , \% 20,5'inin de başka bir işte kısa zamanlı ya da belirli zamanlarda çalıştıkları bulgulanmıştır. 
Öğrencilerin firsat maliyetinin belirlenmesi için bu araştırmada farklı bir yol izlenmiştir. Daha önce de belirtildiği gibi firsat maliyetinin hesaplanmasında asgari ücret tutarları temel alınmaktadır. Araştırmada, öğrencilerin ne kadar gelir elde edebilecekleri kendilerine sorulmuştur. Burada ortalama ve birbirinden çok farklı özelliklere ve aile bağlantılarına sahip öğrencilerin bir örnekleştirilmesi yerine, olası çalışma durumlarını özgün olarak öğrencilerin daha doğru değerlendirebilecekleri sayıltısından hareket edilmiştir. Buna göre öğrenciler aylık ortalama 567 YTL gelir elde edebileceklerini ifade etmişlerdir.

Bir öğretim elemanı başına düşen öğrenci sayısının gelişimi izlendiğinde 1990-1991 yılında öğretim elemanı başına düşen öğrenci sayısı 15 iken 2005-2006 ögretim yılında bu sayı 16 olmuştur. Ara dönemlerde de 11 ile 17 arasında değişmeler gözlenmiştir.

Eğitim Bilimleri Fakültesi öğretim elemanı sayısının 1990-2005 yılları arasında \% 0,9 oranında arttığı görülmüștür. Öğrenci sayısının zamansal gelişimine bakıldığında ise yıllık ortalama \% 1,2 oranında $\operatorname{arttığ~}$ görülmüştür.

Çizelge 10'da elde edilen bütün harcama kalemlerinin toplamı ve vazgeçme maliyetinin de eklenmesiyle tahmini toplumsal maliyete ulaşılmıştır. Özel harcamalar ve vazgeçme maliyeti bütün yıllarda eşit olarak alınmıştır. Sabit yıl olarak 2005 yılı alındığı için bütün yıllara aynı miktarda vazgeçme ve özel harcama miktarları ilave edilmiştir.

Çizelge 10. Tahmini Toplumsal Maliyet (AÜ-EBF; 1990-2005 Dönemi)

\begin{tabular}{ccccc}
\hline Yillar & $\begin{array}{c}\text { Kamusal } \\
\text { Harcama }\end{array}$ & Özel Harcamalar & $\begin{array}{c}\text { Vazgeçme } \\
\text { Maliyeti Miktarı }\end{array}$ & $\begin{array}{c}\text { Toplam Birim } \\
\text { Eğitim Maliyeti }\end{array}$ \\
\hline 1990 & $4.332,79$ & $4.960,80$ & $4.538,16$ & $13.831,75$ \\
\hline 1991 & $4.309,35$ & $4.960,80$ & $4.538,16$ & $13.808,31$ \\
\hline 1992 & $4.711,40$ & $4.960,80$ & $4.538,16$ & $14.210,36$ \\
\hline 1993 & $4.624,27$ & $4.960,80$ & $4.538,16$ & $14.123,23$ \\
\hline 1994 & $3.461,04$ & $4.960,80$ & $4.538,16$ & $12.960,00$ \\
\hline 1995 & $3.410,48$ & $4.960,80$ & $4.538,16$ & $12.909,44$ \\
\hline 1996 & $4.055,40$ & $4.960,80$ & $4.538,16$ & $13.554,36$ \\
\hline 1997 & $5.460,95$ & $4.960,80$ & $4.538,16$ & $14.959,91$ \\
\hline 1998 & $5.156,46$ & $4.960,80$ & $4.538,16$ & $14.655,42$ \\
\hline 1999 & $4.905,59$ & $4.960,80$ & $4.538,16$ & $14.404,55$ \\
\hline 2000 & $4.325,38$ & $4.960,80$ & $4.538,16$ & $13.824,34$ \\
\hline 2001 & $3.512,32$ & $4.960,80$ & $4.538,16$ & $13.011,28$ \\
\hline 2002 & $4.183,63$ & $4.960,80$ & $4.538,16$ & $13.682,59$ \\
\hline 2003 & $4.107,86$ & $4.960,80$ & $4.538,16$ & $13.606,82$ \\
\hline 2004 & $4.866,17$ & $4.960,80$ & $4.538,16$ & $14.365,13$ \\
\hline 2005 & $4.027,15$ & $4.960,80$ & $4.538,16$ & $13.526,11$ \\
\hline
\end{tabular}


Şekil 1'de bulunan harcama miktarlarının yarı logaritmik kalıp yardımıyla başlangıç ve bitiş noktaları belirlenerek zamansal gelişimleri incelenmiştir. Artış olan harcamalar için bir trend doğrusu eklenmiş, azalma olan harcamalar için trend doğrusu eklenmemiştir.

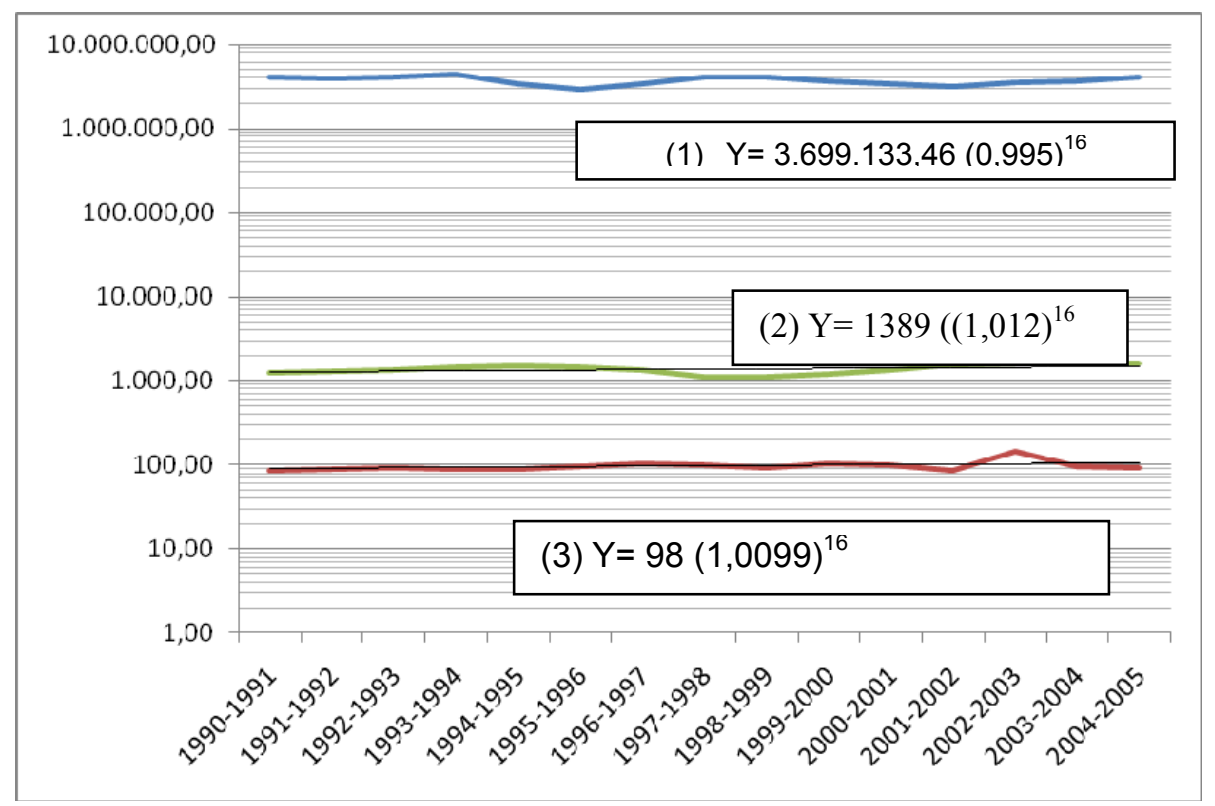

Şekil 1. A.Ü. Eğitim Bilimleri Fakültesi (1) Cari Harcamaları (2005 Yılı Sabit Fiyatları ile YTL Cinsinden), (2) Öğretim Elemanı Sayıları ve (3) Öğrenci Sayılarının Zamansal Gelişimi

1990-2005 yılları arasında Eğitim Bilimleri Fakültesi cari harcamalarına bakıldığında, düşüşler ve dalgalanmalar yaşanmıştır. Yatıım harcamalarında ve transfer harcamalarında yüksek oranda olmasa da bir miktar artışın yaşandığ1 görülmüştür. Öğrenci başına maliyetin giderek düştüğü görülmektedir. Bunun nedeni cari harcamalardaki düşüşün diğer harcamalardaki artıştan yüksek olması nedeniyledir. Bununla birlikte Mezun başına maliyetin de düştüğü gözlenmektedir. Özellikle 2005 yılı mezun sayısındaki artış önceki yıllara göre maliyeti düşürmüştür. Öğrencilerin özel harcamalarının kamusal harcamalara benzer düzeyde olması ailelerin de oldukça yüksek bir eğitim maliyetine katlandıklarını göstermektedir. Öğrencilerin büyük bir çoğunluğunun öğrenim kredisinden yararlandığı, 
buna karşılık katk1 kredisinden ancak \% 50'sinin yararlanabildiği görülmektedir. Öğretim elemanı sayısında sağlanan gelişme öğrenci sayısındaki artıştan daha az düzeyde yaşanmıştır.

A.Ü. Eğitim Bilimleri Fakültesi öğrencilerinin büyük çoğunluğunun emekli, memur ve iş̧̧i çocukları oldukları görülmektedir. Ailede büyük oranda geçimi sağlayan kişi babadır. Belirli bir oranda da geçimini baba ve annenin birlikte karşıladığı görülmüsstür. Baba mesleklerinin büyük bir oranda ilk ve orta düzeyde öğrenim görmüş olması yanında \% 25'lik bir oranda yükseköğrenim gören bulunmaktadır. Düşük gelir grubu içinde yer alan ailelerin gelirlerinin oldukça büyük bir bölümünü eğitim harcamalarına ayırdığı söylenebilir. Öğrencilerin eğitim harcamalarında kalınan yerin ücretinin, yemek ücretlerinin giyim harcamalarının büyük bir ağırlığı olduğu görülmüştür. Öğrencilerin yaşam maliyetleri giderek artmakta, bunun için gerekli geliri sağlayamamaktadırlar. Yaşam maliyetlerindeki artışın nedenleri öğrencilerce hayat pahalılığı, ekonomik koşullar ve öğrenci için gerekli kamusal desteğin azlığı şeklinde ifade edilmektedir. Programlar arasında harcamalar konusunda belirgin farkl1lıklar gözlenmemiştir.

1980'li yıllardan bu yana giderek ağırlığını hissettiren küreselleşmenin olumsuz sonuçlarından eğitim alanının da oldukça etkilendiği bilinmektedir. Elde edilmesi uzun yıllar alan ve çok değerli kazanımlar arasında olan parasız eğitim hakkı kaybolmaya yüztutmuştur. Özellikle yükseköğretimde neoliberal politikaların getirdiği özelleştirme ve paralı eğitim baskısının öğrencilerce açık bir şekilde yaşandığı görülmektedir.

\section{SONUÇ VE ÖNERILER}

Yükseköğretimde yaşanan "yararlanan öder" anlayışına dayanan politikalar sosyal devlet kavramı ve eğitim hakkı ile çatışma yaratan sonuçlar ortaya çıkarmaktadır. Öğrenci ailelerinin gelir yapılarının bu politikaya uygun olmadığı görülmektedir. Yükseköğrenim için yapılan harcamaları karşılamakta sıkıntıya düşen öğrenciler kendilerini akademik ve üniversiter etkinliklere yoğunlaştıramamaktadır.

Harcamalarda olduğu gibi, öğretim elemanı sayılarının da öğrenci sayılarındaki artışa paralel olarak artırılmasının gerektiği görülmektedir. Daha az harcamayla daha fazla öğrenci yetiştirilmesi amacı, öğretim elemanı başına düşen öğrenci sayısının artışı yoluyla eğitimin niteliğini olumsuz yönde etkilemektedir.

Öğrenim kredisinden yararlanan öğrenci sayısı artırılmalıdır. Özellikle harç kredisinden yararlanan öğrencilerin azlığı dikkat çekmektedir. Bunun, 
kredileri geri ödeme konusunda izlenen politikadan kaynaklandığ1 söylenebilir. Staj çalışmalarına başlayan öğrencilerin harcamalarının arttığı belirlenmiştir. Bu da öğrenciye ayrı bir mali yük getirmektedir. Staj yapan öğrencilerin öğrenim kredisi miktarlarında bu dönemlerin dikkate alınması ve öğrencilere ek bir ödemenin yapılması düşünülebilir. Ayrıca, harç uygulamalarının ve buna karşılık zaten yetersiz verilen katkı kredisinin kaldırılması yoluyla en azından öğrenciler üzerindeki eğitimin doğrudan maliyet yükünün azaltılması yoluna gidilmelidir.

Tüm bu uygulamalar asıl olarak yükseköğretim de dahil olmak üzere, eğitimin bir insan hakkı olduğu, ekonomik ve diğer koşullarından bağımsız olarak herkes için ulaşılabilir olması gerektiğini unutturmamalıdır. Finansman politikası konusundaki çabaların eğitim hakkının güçlendirilmesine ya da geriletilmesine olan etkisi de unutulmamalıdır.

\section{KAYNAKÇA}

Adem, M. (1977). Türk Eğitiminin Ekonomi Politikası. Yayımlanmamış Doçentlik Tezi, Ank., Ankara Üniversitesi Sosyal Bilimler Enstitüsü.

Adem, M. (1981). Eğitim Planlamasl. Ankara: Ankara Üniversitesi Eğitim Bilimleri Fakültesi Eğitim Araştırmaları Merkezi Yayını.

Akalın, G. (1980). Yüksekögretim Karma Malına Maliyet Fayda Analizinin Uygulanması. Ankara Üniversitesi Siyasal Bilgiler Fakültesi Yayını: Ank.

Aksoy, Hasan H. (Aralık 2005). Küresel Kapitalizmin Kamusal Eğitime Etkileri. Abece Eğitim ve Ekin Dergisi, 232, 2-7.

Aksoy, Hasan H. (1991). Mesleki ve Teknik Eğitim Yatırım Projelerinin Gerçekleşme Durumları (1976-1985 Dönemi) Ankara Üniversitesi Eğitim Bilimleri Fakültesi Dergisi. 24(2), 822-829.

Aksoy, Hasan H. (1991) Ortaöğretim Düzeyindeki Din Eğitimi Okulları ve Diğer Meslek Liselerinin Sayısal Gelişmeleri. Ankara Üniversitesi Eğitim Bilimleri Fakültesi Dergisi. 26 (2), 145-162.

Balc1, A. (1997). Soysal Bilimlerde Araştırma: Yöntem, Teknik ve İlkeler. Ankara: 72 TDFO Bilgisayar-Yayıncılık San. Tic. Ltd. Şti.

Bottomley, J.A. (1972). Cost and Potential Economies. Paris: OECD.

Bulmuş, İ. (1998). Mikro İktisat. Ankara: Cantekin Matbaası.

Çınkır, Ş. (2001) Maliyet-Fayda Analizi: Gelişmekte Olan Ülkelerde Eğitim Planlaması İle Politika Kararlarının Alınmasına Katkısı. Eğitim Araştırmaları Dergisi. (1), 21-26.

Dinler, Z. (2005). İkitisada Giriş. Bursa: Ekin Kitabevi.

DPT, Sosyal Planlama Başkanlığı (1989). Türkiye'de Öğrenci Maliyetleri (1979-1987). Ankara: DPT Yayınları.

Edizdoğan, N. (1995). Kamu Bütçesi . Bursa: Ekin Kitabevi. 
Eide, K. (1969) The Cost Structure of Turkish Higher Education. Ankara: DPT Yayınları.

Ergen, H. (1999). Türkiye'de Eğitim Harcamalarının Analizi ve Yükseköğretimde Maliyetler, Ank. Yayımlanmamış Yüksek Lisans Tezi, Hacettepe Üniversitesi Sosyal Bilimler Enstitüsü.

Ertek, T. (2005). Mikroekonomiye Giriş. İstanbul: Beta Yayın Dağıtım A.Ş.

Ertek, T. (2000). Ekonometriye Giriş. İstanbul: Beta Basım Yayım Dağıtım A.Ş.

Hallak, J. (1974). Eğitimde Maliyet ve Harcamalar. Ankara: Talim ve Terbiye Dairesi Yayınları, Milli Eğitim Basımevi.

Karakütük, K. (2001). "Yükseköğretimde Finansman Darboğazı ve Vakıf Yükseköğretim Kurumlarına Yapılan Parasal Devlet Yardımları" Eğitim Araştırmaları Dergisi. (3-4), 70-82.

Karakütük, K. (1991). Mesleki Teknik Ortaöğretimin Verimliliği. Ankara Üniversitesi Ĕ̈itim Bilimleri Fakültesi Dergisi. 24(2), 803-819.

Karasar, N. (2002). Bilimsel Araştırma Yöntemi. Ankara: Nobel Yayınc1lık.

Maliye Bakanlığı. (1992). "Katma Bütçeli Kuruluşların Kesin Hesap Cetveli (1990-2005), Ankara: Maliye Bakanlığı Muhasebat Genel Müdürlüğü.

Nazenin, Ü. (2002). Türkiye'de Devletin Üniversitelere Yaptı̆̆ 1 Harcamaların Neoliberal Eğitim Politikaları Bağlamında Cözümlenmesi. Yayımlanmamış Yüksek Lisans Tezi, Ank. Ankara Üniversitesi Eğitim Bilimleri Enstitüsü.

Öğrenci Seçme ve Yerleştirme Merkezi. (1986). 1985-1986 Öğretim Yll Yüksekögrretim İstatistikleri. Ankara: ÖSYM.

Öğrenci Seçme ve Yerleştirme Merkezi. (2005). 2004-2005 Öğretim Yllı Yüksekögretim İstatistikleri. Ankara: ÖSYM.

Özsoy, S. (2002). Yükseköğretimde Hakkaniyet ve Eşitlik Sorunsalı: Türkiye'deki Finansal Yap1 İle İlgili Bir Çözümleme, Ank. Yayımlanmamış Doktora Tezi. Ankara Üniversitesi Sosyal Bilimler Enst.

Psacharapoulos. G. (1995). "İnsangücü Planlamasından İşgücü Piyasası Çözümlemesine". (Çev. H. H. Aksoy). Ankara Üniversitesi Ĕgitim Bilimleri Fakültesi Dergisi, 26(2), 429-442.

Serin, N. (1979). Eğitim Ekonomisi. Ankara: Ankara Üniversitesi Eğitim Bilimleri Fakültesi Yayını.

Timur, T. (2000). Toplumsal Değişme ve Üniversiteler. Ankara: İmge Kitapevi.

TUIK, (2006), Haber Bülteni. T.C. Başbakanlık İstatistik Kurumu, Ankara: TUIK Yayınları.

Tural, N. (2004). Küreselleşme ve Üniversiteler. Ankara: Kök Yayıncılık.

Tural, N.(2002). Eğitim Finansmanı. Ankara: Anı Yayıncılık.

Türkay, O. (1996). Mikroiktisat Teorisi. Ankara: İmaj Yayıncılık.

Ünal, L. I. (1986). Eğitim ve Yetiştirme Ekonomisi. Ankara: EPAR Yayınları. 
